Article

\title{
The Effectiveness of Different Rootstocks for Improving Yield and Growth of Cucumber Cultivated Hydroponically in a Greenhouse
}

\author{
Ali Farhadi $1,2, *$, Hossain Aroeii ${ }^{2}$, Hossain Nemati ${ }^{2}$, Reza Salehi ${ }^{3}$ and Francesco Giuffrida ${ }^{4}$ \\ Received: 20 September 2015; Accepted: 7 December 2015; Published: 6 January 2016 \\ Academic Editors: Douglas D. Archbold and Stefania de Pascale \\ 1 Agriculture and Natural Resource Research Center of Isfahan, Isfahan 8174835117, Iran \\ 2 Department of Horticulture Sciences, Agriculture Faculty, Ferdowsi University of Mashhad, \\ Mashhad 9177948978, Iran; aroiee@um.ac.ir (H.A.); nematih@yahoo.com (H.N.) \\ 3 Department of Horticultural Sciences, Campus of Agriculture \& Natural Resources, University of Tehran, \\ Karaj 3158777871, Iran; salehir@ut.ac.ir \\ 4 Department of Agriculture, Food and Environment, Catania University, Catania 95100, Italy; \\ francesco.giuffrida@unict.it \\ * Correspondence: farhadi_siv@yahoo.com
}

\begin{abstract}
The use of grafted vegetable seedlings has been popular in many countries during recent years, and several Cucurbita species and their interspecific hybrids have been tested as rootstocks. Graft-scion incompatibility and lower fruit quality have prevented their commercial use. In this study, the efficacy of grafting the commercial Khassib cucumber hybrid onto various cucurbits, used as rootstocks, was examined in a greenhouse experiment. This experiment was done in a completely randomized design with eight treatments: local landraces of bottle gourd (Ghalyani) and pumpkin (Tanbal) and commercial Cucurbita interspecific hybrids (909, 913, Ferro, 64-19, and Shintoza). Ungrafted plants were used as controls. Results indicated that the highest survival rates were using Ferro hybrid (94\%), Cucurbita maxima (Tanbal) (92\%), 64-19 and Shintoza (90\%). These results appeared to be related to the stem diameter of the rootstocks and, to a lesser extent, to the scion diameter. Cucumber production was not improved by grafting. The highest yield was obtained with Ferro rootstock, but it was no different compared to ungrafted plants. A significantly lower production than the control was observed with Ghalyani $(-44 \%), 913(-73 \%)$ and $64-19$ $(-35 \%)$ rootstocks. Total soluble solids (TSS) of fruit produced by ungrafted plants was significantly higher than the other treatments. The highest length/diameter ratio was obtained with 909 and Ghalyani rootstocks, whereas more stocky fruit were produced by plants grafted onto Tanbal and 64-19 rootstocks.
\end{abstract}

Keywords: Cucumis sativus L.; soilless; protected cultivation; production; grafting; quality

\section{Introduction}

Cucumber (Cucumis satious L.) is one of the most popular vegetables in the world, and annually about 71.4 million tons are produced [1]. Cucumber is also an important vegetable crop for greenhouse production in many countries. Continuous cultivation in greenhouses leads to some problems, including soil-borne diseases, soil nutrient imbalances, salty or alkaline soil conditions, spread of weeds, etc. To alleviate these problems, grafting is recommended. Grafting is an important technique for vegetable production in many countries where intensive and continuous cultivation is performed. Vegetable grafting has been used to improve yield, fruit quality and disease resistance in Solanaceae and Cucurbitaceae [2-5]. In recent years, grafting has been found effective in overcoming abiotic stresses. 
Numerous studies have reported that different rootstock genotypes could have variable effects on yield and quality of the grafted vegetable, and the overall performance largely depends on the specificity of the rootstock-scion combination [6-8].

Several Cucurbita species and their interspecific hybrids have been used traditionally as rootstocks for cucumber. The performance of the grafted plants, including fruit quality, depends on rootstock-scion interactions and on the cultivation method. Some rootstocks have been reported to positively affect yield and fruit quality. However, graft incompatibility and a decrease in quality appears in most cases [6]. Some authors associate this decline in quality with the translocation of fruit quality agents from the Cucurbita rootstock to the cucumber scion. The use of rootstocks belonging to the same species (C. sativus) has been proposed as a method to overcome these problems [9].

In some developing countries, vegetable grafting is not popular with farmers, and the use of local landraces is common for vegetable crops. The aim of the research was to assess the compatibility of local landraces and interspecific hybrids as rootstocks for cucumber cultivation in terms of yield and quality.

\section{Experimental Section}

\subsection{Plant Material, Treatments and Growth Conditions}

The experiment was conducted in autumn-winter 2014 in a glasshouse situated in the Dastgerd Experimental Station of the Agricultural and Natural Resources Research Center of Isfahan, Central Iran (latitude $32^{\circ} 36^{\prime} \mathrm{N}$, longitude $51^{\circ} 36^{\prime} \mathrm{E}, 1576 \mathrm{~m}$ above sea level). Cucumis sativus L. cv. Khassib $\mathrm{F}_{1}$ (Rijk Zwaan, Fijnaart, The Netherlands) was grafted onto five interspecific hybrids (Shintoza, 909, 913, Ferro and 64-19), one local landrace of pumpkin (Cucurbita maxima L. (Tanbal)) and one of bottle gourd (Lagenaria siceraria (Ghalyani)) using the "splice grafting" described by Lee [10], whereas ungrafted "Khassib" was used as a control. Rootstock and scion seeds were sown on 10 and 14 September 2014, respectively. They were grafted on 22 September 2014. Grafted plants were kept in a small tunnel under semi-controlled environmental conditions. Seedlings grew without light and with a $>90 \% \mathrm{RH}$ (Relative Humidity) for four days, then light was gradually increased and relative humidity was decreased. At the two true-leaf stage (7 October 2014), grafted plants were transplanted to $10 \mathrm{~L}$ plastic pots. The substrate was perlite and coco peat $(60: 40 \mathrm{v} / \mathrm{v})$. The space between plant pots was $35 \mathrm{~cm}$ in the rows and $70 \mathrm{~cm}$ between rows, obtaining a plant density of four plants $/ \mathrm{m}^{2}$. Plants were grown under natural light conditions. During the whole crop cycle, air temperatures inside the greenhouse were recorded daily (Figure 1). The experiment was set up in a completely randomized design with three replicates for each treatment. Each experimental unit consisted of eight plants. Throughout the experiment, a modified Hoagland nutrient solution was used: $\mathrm{Ca}\left(\mathrm{NO}_{3}\right)_{2}(35 \mathrm{~g} / \mathrm{L}) ; \mathrm{NH}_{4} \mathrm{NO}_{3}(18 \mathrm{~g} / \mathrm{L})$; $\mathrm{KNO}_{3}(62 \mathrm{~g} / \mathrm{L}) ;$ FeEDDHA $(1.17 \mathrm{~g} / \mathrm{L}) ; \mathrm{KH}_{2} \mathrm{PO}_{4}(15 \mathrm{~g} / \mathrm{L}) ; \mathrm{MgSO}_{4}(32 \mathrm{~g} / \mathrm{L}) ; \mathrm{MnSO}_{4}(0.062 \mathrm{~g} / \mathrm{L}) ;$ $\mathrm{ZnSO}_{4} \cdot 2 \mathrm{H}_{2} \mathrm{O}(0.018 \mathrm{~g} / \mathrm{L}) ; \mathrm{CuSO}_{4} \cdot 5 \mathrm{H}_{2} \mathrm{O}(0.004 \mathrm{~g} / \mathrm{L}) ; \mathrm{H}_{3} \mathrm{BO}_{3}(0.077 \mathrm{~g} / \mathrm{L}) ; \mathrm{Na}_{2} \mathrm{MoO}_{4}(0.0015 \mathrm{~g} / \mathrm{L})$ [11]. The corresponding EC (Electrical Conductivity) of the nutrient solution was $2 \pm 0.2 \mathrm{dS} / \mathrm{m}$.

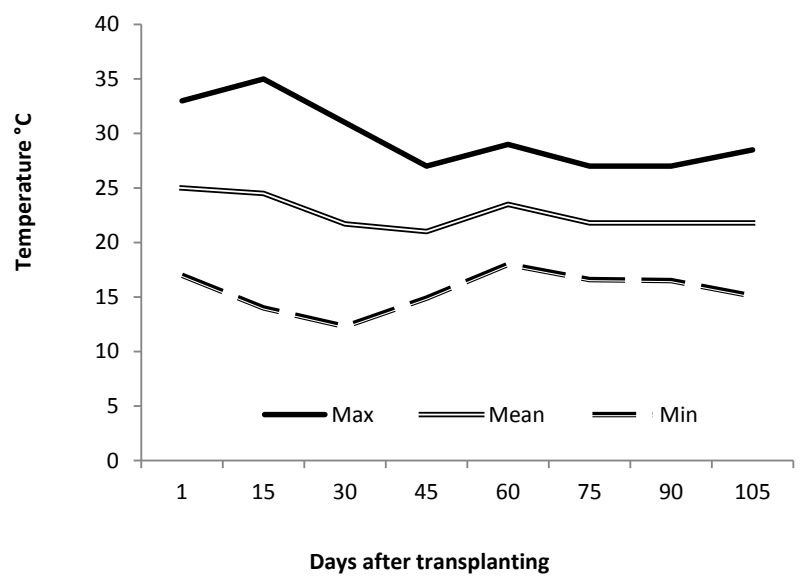

Figure 1. Air temperature inside the greenhouse during the experiment. 


\subsection{Survival Rate and Plant Growth}

The surviving grafted plants were counted $15 \mathrm{~d}$ after grafting, and the survival rate was calculated.

Plant height, rootstock and scion stem diameter were measured in each treatment. A ruler was used for plant height, with measurement from the substrate surface to the top of the plant. Diameter measurements were made using a digital caliper and were taken $1 \mathrm{~cm}$ below and above the graft union. Dry matter production of plant organs (root and shoot g/plant) was determined by drying at $72{ }^{\circ} \mathrm{C}$ for $48 \mathrm{~h}$ in a thermo-ventilated oven at the end of the growing period. The lengths of the roots and leaf area were measured at the end of the crop.

\subsection{Yield and Fruit Quality Parameters}

Harvest was started $36 \mathrm{~d}$ after transplanting. Harvested fruits were weighed and counted. Total yield, total fruit number, and total marketable and unmarketable fruit (lacking uniformity and/or fruits with physiological disorders) were counted.

\subsection{Statistical Analysis}

All data were statistically analyzed performing ANOVA with CoStat software. Means were separated using Duncan's Multiple Range Test at $\alpha=0.05$.

\section{Results}

\subsection{Plant Growth}

High compatibility between scion and rootstock and survival was achieved with Ferro hybrid (94\%), Cucurbita maxima (Tanbal) (92\%), 64-19 and Shintoza (Figure 2). The lowest survival rates were observed with Lagenaria siceraria (Ghalyani) (72\%) and 913 hybrids (73\%).

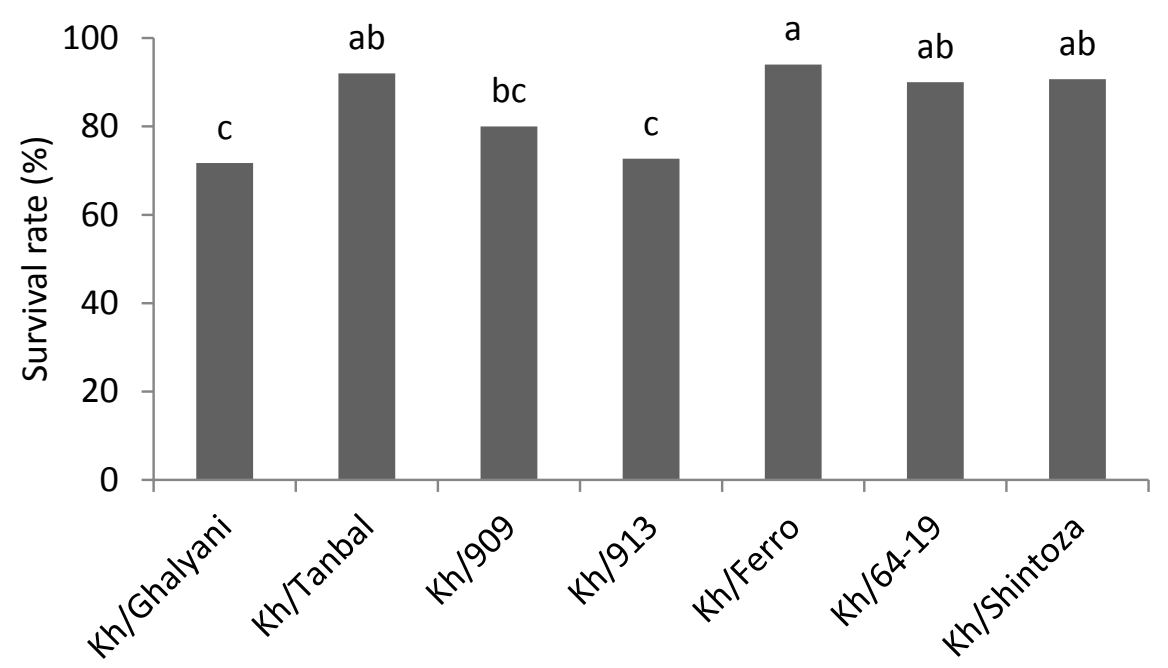

Figure 2. The survival rate of the Khassib cucumber grafted onto different rootstocks (Kh $=$ Khassib scion). Bars with different letters differ statistically at $\alpha=0.05$ by Duncan's Multiple Range Test.

The rootstock diameter at $15 \mathrm{~d}$ after transplanting (DAT) was not affected by grafting, but at the end of the experiment, the diameters showed significant differences (Figure 3). Ferro ( $8.65 \mathrm{~mm}$ ), Tanbal and 64-19 hybrid $(7.95 \mathrm{~mm})$ had a higher hypocotyl diameter than Shintoza $(5.77 \mathrm{~mm})$ and Ghalyani $(6 \mathrm{~mm})$. Significant differences were observed in the scion diameter on different rootstocks at 15 DAT and 100 DAT (Figure 4). At 15 DAT, the scion diameter of plants grafted onto 909 was higher than all the other rootstock treatments except for Ferro and 64-19, which were the highest at the end of the experiment (100 DAT). 


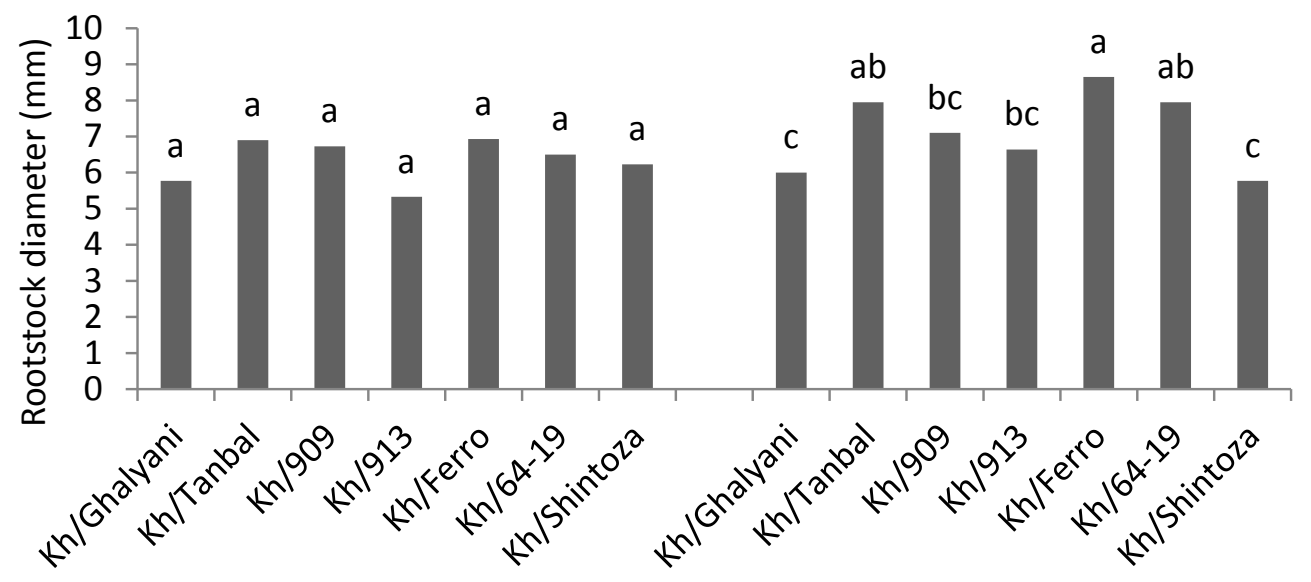

15 Day After Transplant

100 Day After Transplant

Figure 3. Rootstock diameter at two stages of plant growth $(\mathrm{Kh}=\mathrm{Khassib}$ scion). Bars with different letters differ statistically at $\alpha=0.05$ (Duncan's Multiple Range Test).

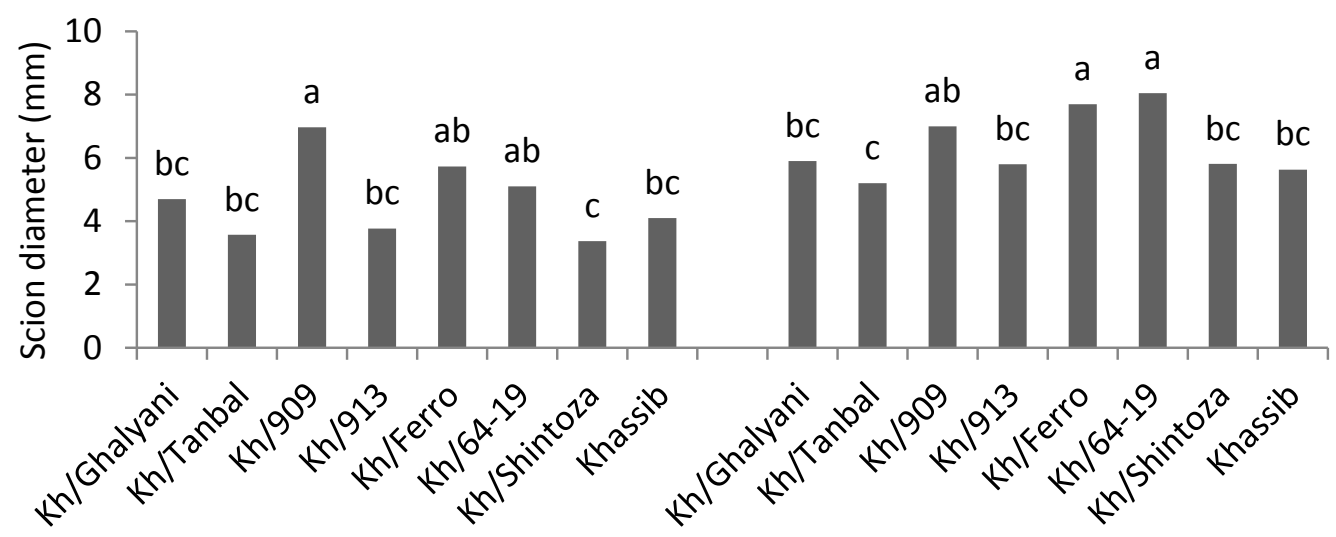

15 Day After Transplant

100 Day Aftar Transplant

Figure 4. Scion diameter at two stages of plant growth $(\mathrm{Kh}=\mathrm{Khassib}$ scion). Bars with different letters differ statistically at $\alpha=0.05$ (Duncan's Multiple Range Test).

At the end of the experiment, rootstocks significantly influenced plant growth (Table 1). Root dry biomass was the lowest with Ghalyani, reduced by about $80 \%$ compared to ungrafted plants. Although greater than Ghalyani, pumpkin and 913 hybrid rootstocks were significantly lower than the other rootstocks. Root length was only partially related to root biomass, highlighting a different ranking for root density among the rootstocks. In particular, 913 and Ferro hybrids had the highest root length but root biomass in 913 was about 55\% lower than in Ferro.

Ferro rootstock was the only one with greater growth $(+15 \%)$ than ungrafted plants (Table 1$)$. The other rootstocks (except 909) produced a lower shoot dry biomass compared to the control, with the greatest reduction with Ghalyani $(-60 \%)$. Concerning the Root/Shoot (R/S) ratio, Shintoza rootstock showed a higher value compared to the control, whereas the other treatments did not differ from ungrafted plants.

The Shintoza hybrid produced the tallest plant and the highest internode number (Table 1). All other treatments showed values similar or lower than the control. The leaf area showed a high 
variability among treatments with a lower value with Ghalyani compared to Tanbal, and all others were between these.

Table 1. Effects of rootstocks on cucumber plant growth (cv. Khassib).

\begin{tabular}{|c|c|c|c|c|c|c|c|}
\hline Treatments & $\begin{array}{l}\text { Root Dry } \\
\text { Weight } \\
\text { (g/plant) }\end{array}$ & $\begin{array}{l}\text { Root } \\
\text { Length } \\
\text { (cm) }\end{array}$ & $\begin{array}{l}\text { Shoot Dry } \\
\text { Weight } \\
\text { (g/plant) }\end{array}$ & $\mathrm{R} / \mathrm{S}$ & $\begin{array}{c}\text { Plant } \\
\text { Height } \\
\text { (cm) }\end{array}$ & $\begin{array}{c}\text { Node } \\
\text { Number }\end{array}$ & $\begin{array}{l}\text { Leaf Area } \\
\left(\mathrm{cm}^{2} / \text { plant }\right)\end{array}$ \\
\hline Kh/Ghalyani & $0.52 c$ & $37.5 \mathrm{c}$ & $6.4 \mathrm{e}$ & $0.11 \mathrm{c}$ & $60.7 \mathrm{f}$ & $18 \mathrm{~d}$ & $480.8 \mathrm{~b}$ \\
\hline Kh/Tanbal & $1.58 \mathrm{~b}$ & $52.0 \mathrm{ab}$ & $12.7 \mathrm{C}$ & $0.12 c$ & $98.0 \mathrm{e}$ & $23 \mathrm{~cd}$ & $904.4 \mathrm{a}$ \\
\hline $\mathrm{Kh} / 909$ & $2.16 \mathrm{a}$ & $48.0 \mathrm{abc}$ & $15.3 \mathrm{~b}$ & $0.14 b c$ & $146.5 \mathrm{~cd}$ & $31 \mathrm{bc}$ & $634.1 \mathrm{ab}$ \\
\hline $\mathrm{Kh} / 913$ & $1.23 \mathrm{~b}$ & $57.0 \mathrm{a}$ & $8.5 \mathrm{~d}$ & $0.15 \mathrm{bc}$ & $95.0 \mathrm{e}$ & $16 \mathrm{~d}$ & $558.5 \mathrm{ab}$ \\
\hline $\mathrm{Kh} /$ Ferro & $2.73 \mathrm{a}$ & $59.0 \mathrm{a}$ & $18.7 \mathrm{a}$ & $0.15 \mathrm{bc}$ & $161.5 \mathrm{bc}$ & $32 \mathrm{~b}$ & $612.9 \mathrm{ab}$ \\
\hline Kh/64-19 & $2.34 \mathrm{a}$ & $47.0 \mathrm{abc}$ & $11.9 \mathrm{c}$ & $0.20 \mathrm{ab}$ & $130.5 \mathrm{~d}$ & $33 \mathrm{~b}$ & $555.5 \mathrm{ab}$ \\
\hline Kh/Shintoza & $2.35 \mathrm{a}$ & $41.0 \mathrm{bc}$ & $10.8 \mathrm{c}$ & $0.22 \mathrm{a}$ & $241.0 \mathrm{a}$ & $43 \mathrm{a}$ & $613.5 \mathrm{ab}$ \\
\hline Ungrafted & $2.49 \mathrm{a}$ & $48.0 \mathrm{abc}$ & $15.9 \mathrm{~b}$ & $0.16 \mathrm{bc}$ & $179.5 \mathrm{~b}$ & $28 \mathrm{bc}$ & $734.2 \mathrm{ab}$ \\
\hline Significance $\mathbf{1}$ & $* * *$ & * & $* * *$ & * & $* * *$ & $* * *$ & * \\
\hline
\end{tabular}

\subsection{Yield Parameters}

Cucumber production was not improved by grafting (Table 2). The highest yield for rootstocks was obtained with Ferro, but it was no different than that for ungrafted plants. A significantly lower production than the control was observed with Ghalyani $(-44 \%), 913(-73 \%)$ and $64-19(-35 \%)$ rootstocks, and these results were mainly due to fruit number. As for marketable fruit, the lowest value was from 913 with $68.7 \%$.

Table 2. Effects of rootstocks on cucumber yield and quality.

\begin{tabular}{|c|c|c|c|c|c|c|c|}
\hline Treatments & $\begin{array}{l}\text { Yield } \\
\left(\mathrm{g} / \mathrm{m}^{2}\right)\end{array}$ & $\begin{array}{c}\text { Fruit } \\
\text { Number } \\
\text { (n/plant) }\end{array}$ & $\begin{array}{l}\text { Marketable } \\
\text { Fruit (\%) }\end{array}$ & $\begin{array}{l}\text { TSS } \\
\text { (Brix) }\end{array}$ & $\begin{array}{c}\text { Fruit Dry } \\
\text { Weight (g) }\end{array}$ & $\begin{array}{c}\text { Fruit } \\
\text { Diameter } \\
\text { (cm) }\end{array}$ & $\begin{array}{c}\text { Fruit } \\
\text { Shape } \\
\text { (L/D) }^{2}\end{array}$ \\
\hline Kh/Ghalyani & 2954 de & 13.7de & $82.0 \mathrm{bc}$ & $3.3 \mathrm{~cd}$ & $3.66 \mathrm{~b}$ & $2.6 \mathrm{bc}$ & $4.2 \mathrm{a}$ \\
\hline Kh/Tanbal & 4096 bc & $16.0 \mathrm{~cd}$ & $96.5 \mathrm{a}$ & $3.5 \mathrm{bc}$ & $4.98 \mathrm{a}$ & $3.1 \mathrm{a}$ & $3.2 \mathrm{c}$ \\
\hline $\mathrm{Kh} / 909$ & 4946 bc & $23.7 \mathrm{abc}$ & $80.9 \mathrm{~cd}$ & $3.9 \mathrm{~b}$ & $4.23 \mathrm{ab}$ & $2.5 \mathrm{c}$ & $4.7 \mathrm{a}$ \\
\hline $\mathrm{Kh} / 913$ & $1384 \mathrm{e}$ & $5.25 \mathrm{e}$ & $68.7 \mathrm{~d}$ & $3.2 \mathrm{~cd}$ & $3.39 \mathrm{~b}$ & $2.9 \mathrm{ab}$ & $3.7 \mathrm{ab}$ \\
\hline Kh/Ferro & $6657 \mathrm{a}$ & $29.5 \mathrm{a}$ & $94.7 \mathrm{ab}$ & $3.2 \mathrm{~cd}$ & $3.39 \mathrm{~b}$ & $2.9 \mathrm{ab}$ & $3.4 \mathrm{bc}$ \\
\hline Kh/64-19 & $3407 \mathrm{~cd}$ & $16.1 \mathrm{~cd}$ & $91.8 \mathrm{abc}$ & $3.9 \mathrm{~b}$ & $3.69 \mathrm{~b}$ & $2.6 \mathrm{bc}$ & $3.1 \mathrm{c}$ \\
\hline Kh/Shintoza & $4337 \mathrm{bc}$ & $20.0 \mathrm{bcd}$ & $80.0 \mathrm{~cd}$ & $2.9 \mathrm{~d}$ & $4.87 \mathrm{a}$ & $2.7 \mathrm{abc}$ & $3.5 \mathrm{bc}$ \\
\hline Ungrafted & $5234 \mathrm{ab}$ & $27.0 \mathrm{ab}$ & $90.5 \mathrm{abc}$ & $4.8 \mathrm{a}$ & $5.15 \mathrm{a}$ & $2.4 \mathrm{c}$ & $3.7 \mathrm{ab}$ \\
\hline Significance ${ }^{1}$ & $* * *$ & $* * *$ & $* *$ & $* * *$ & $* *$ & $* *$ & $* *$ \\
\hline
\end{tabular}

\subsection{Fruit Quality Analysis}

Total soluble solids (TSS) of fruit produced by the ungrafted plants were significantly higher than other treatments (Table 2). Fruit from Shintoza had the lowest TSS, 39\% lower than the control. TSS content was not directly related to fruit dry weight. In fact, the highest value was observed with ungrafted plants and Shintoza and Tanbal rootstocks. The ungrafted plants had $34 \%$ more fruit dry matter than those grafted onto 913 rootstock. The use of different rootstocks led to changes in fruit size and shape. The highest length/diameter ratio was obtained with 909 and Ghalyani, whereas more stocky fruit were produced by plants grafted onto Tanbal and 64-19. 


\section{Discussion}

In this experiment, plants with a thicker diameter stem reflected increased graft compatibility (Figures 2-4). There have been differing opinions on whether a difference in hypocotyl diameter between scion and rootstock affects graft incompatibility. Oda et al. [12] and Traka-Mavrona et al. [13] reported that smaller differences in hypocotyl diameters between the cucumber scion and squash rootstock may increase compatibility regardless of the quantity of vascular bundles. On the contrary, Edelstein et al. [6] did not observe any correlation between the difference of the scion and rootstock hypocotyl diameters or vascular bundles and the survival rate of grafted plants, concluding that the different results were attributed to the grafting techniques. A low survival rate in grafted plants can be due to two main characteristics: (1) the removal of the cotyledons from the rootstock; and (2) the limited number of the vascular bundles that connect the scion to the rootstock [12].

Since the root systems of selected rootstocks are usually much larger and more vigorous, they can absorb water and nutrients much more efficiently as compared to non-grafted plants [3]. However, in this research, we found a positive relation between root growth and biomass and fruit production only using Ferro as a rootstock. In the other scion/rootstock combinations, no clear relation was found between root vigor and scion response. In this regard, plant growth and production could be influenced by hormonal signals from the rootstock that could alter shoot physiology $[5,14]$. Cucurbit plant stems usually secrete xylem sap when decapitated, which is greatly influenced by the rootstock and contains high concentrations of minerals and plant hormones. This may explain the growth promotion of the cucumbers observed in our experiments when Cucurbita rootstocks were used.

The use of Ferro rootstock significantly increased the total fruit yield compared to the other rootstocks and did not differ from ungrafted plants. Therefore, this rootstock can be used in our conditions against some soil-borne pathogens typical of greenhouse conditions. As regards landraces, Lagenaria siceraria gave the lowest cucumber production. Plants grafted onto Tanbal, Ferro and 64-19, as well as ungrafted plants, showed a greater percentage of marketable fruit. In contrast, a higher marketable yield using grafted watermelon was obtained by Colla et al. [15] in Mediterranean climatic conditions.

The results of this research also showed that the TSS of fruit produced by ungrafted plants was significantly higher than in other treatments, as was previously found by López-Galarza et al. [16] in watermelon.

\section{Conclusions}

In conclusion, graft compatibility, measured in terms of plant survival after grafting, appeared to be related to the stem diameter of the rootstocks and, to a lesser extent, to scion diameter. Some C. maxima $\times$ C. moschata rootstocks had a similar production to ungrafted plants; thus, these rootstocks could be used for their resistance against soil-borne disease and not for their vigor. After the elimination of methyl bromide, grafting is one of the most effective alternatives worldwide to control root diseases of greenhouse vegetables. However, the high cost of grafted plants is the main problem for the widespread use of vegetable grafting. For these reasons, in developing countries vegetable grafting is still rare compared to the use of grafting in tree crops. The use of local landraces as rootstocks could help decrease the cost of grafted plants. However, our results using local landraces highlighted the importance of checking the grafting compatibility with the most important hybrid used as a scion under biotic and abiotic stresses.

Author Contributions: This work was a product of the combined effort of all authors. Ali Fharadi performed the experiments, gathered and analyzed the data, and wrote the manuscript with the help of Hossain Aroeii, Hossain Nemati and Reza Salehi. Francesco Giuffrida revised and improved the manuscript.

Conflict of Interest: The authors declare no conflict of interest. 


\section{References}

1. FAO. Statistics at FAO. Available online: www.fao.org/statistics/en (accessed on 25 December 2015).

2. Kubota, C.; McClure, M.A.; Kokalis-Burelle, N.; Bausher, M.G.; Rosskopf, E.N. Vegetable grafting: History, use, and current technology status in north America. HortScience 2008, 43, 1664-1669.

3. Lee, J.M.; Kubota, C.; Tsao, S.J.; Bie, Z.; Echevarria, P.H.; Morra, L.; Oda, M. Current status of vegetable grafting: Diffusion, grafting techniques, automation. Sci. Hort. 2010, 127, 93-105. [CrossRef]

4. Savvas, D.; Colla, G.; Rouphael, Y.; Schwarz, D. Amelioration of heavy metal and nutrient stress in fruit vegetables by grafting. Sci. Hort. 2010, 127, 156-161. [CrossRef]

5. Schwarz, D.; Rouphael, Y.; Colla, G.; Venema, J.H. Grafting as a tool to improve tolerance of vegetables to abiotic stresses: Thermal stress, water stress and organic pollutants. Sci. Hort. 2010, 127, 162-171. [CrossRef]

6. Edelstein, M.; Burger, Y.; Horev, C.; Porat, A.; Meir, A.; Cohen, R. Assessing the effect of genetic and anatomic variation of Cucurbita rootstocks on vigour, survival and yield of grafted melons. J. Hort. Sci. Biotechnol. 2004, 79, 370-374.

7. Cohen, R.; Burger, Y.; Horev, C.; Koren, A.; Edelstein, M. Introducing grafted cucurbits to modern agriculture: The Israeli experience. Plant Dis. 2007, 91, 916-923. [CrossRef]

8. Davis, A.R.; Perkins-Veazie, P.; Hassell, R.; Levi, A.; King, S.R.; Zhang, X. Grafting effects on vegetable quality. HortScience 2008, 43, 1670-1672.

9. Rouphael, Y.; Schwarz, D.; Krumbein, A.; Colla, G. Impact of grafting on product quality of fruit vegetables. Sci. Hort. 2010, 127, 172-179. [CrossRef]

10. Lee, J.M. Cultivation of grafted vegetables: 1. Current status, grafting methods, and benefits. HortScience 1994, 29, 235-239.

11. Zhang, Z.; Liu, S.; Hao, S.; Liu, S. Grafting increases the copper tolerance of cucumber seedlings by improvement of polyamine contents and enhancement of antioxidant enzymes activity. Agr. Sci. China 2010, 9, 985-994. [CrossRef]

12. Oda, M.; Tsuji, K.; Sasaki, H. Effect of hypocotyl morphology on survival rate and growth of cucumber seedling grafted on Cucurbita spp. Jap. Agr. Res. Quart. 1993, 26, 259-263.

13. Traka-Mavrona, E.; Koutsika-Sotiriou, M.; Pritsa, T. Response of squash (Cucurbita spp.) as rootstock for melon (Cucumis melo L.). Sci. Hort. 2000, 83, 353-362. [CrossRef]

14. Pérez-Alfocea, F.; Albacete, A.; Ghanem, M.E.; Dodd, I.C. Hormonal regulation of source-sink relations to maintain crop productivity under salinity: A case study of root-to-shoot signaling in tomato. Funct. Plant Biol. 2010, 7, 592-603. [CrossRef]

15. Colla, G.; Rouphael, Y.; Cardarelli, M.; Salerno, A.; Rea, E. The effectiveness of grafting to improve alkalinity tolerance in watermelon. Environ. Experim. Bot. 2010, 68, 283-291. [CrossRef]

16. Lopez-Galarza, S.; San Bautista, A.; Perez, D.M.; Miguel, A.; Baixauli, C.; Pascual, B.; Maroto, J.V.; Guardiola, J.L. Effects of grafting and cytokinin-induced fruit setting on colour and sugar-content traits in glasshouse-grown triploid watermelon. J. Hort. Sci. Biotechnol. 2004, 79, 971-976.

(C) 2016 by the authors; licensee MDPI, Basel, Switzerland. This article is an open access article distributed under the terms and conditions of the Creative Commons by Attribution (CC-BY) license (http://creativecommons.org/licenses/by/4.0/). 